\title{
STUDY OF FISH COMMUNITIES IN THE SIRET RIVER, AND SOME TRIBUTARIES (BACAU - RACACIUNI SECTION, 2012-2016)
}

\author{
Ureche Dorel, Ureche Camelia \\ "Vasile Alecsandri" University of Bacău, Romania, dureche@ub.ro, urechec@ub.ro \\ https://doi.org/10.53937/9789975315975.84
}

\begin{abstract}
The study was carried out in Bacau - Racaciuni section of Siret River, on the main course of the river and on some of its tributaries during the period 2012-2016. The aim of our research study was to assess the actual state of fish communities in the study area, and also to highlight significant changes in fish communities, based on the ecological analysis. The biological material was sampled by electrofishing from 16 sampling sites, and then it was determined and immediately released. The taxonomic analysis highlights the presence of 27 fish species, two of them being non-native: Psedorasbora parva, and Perccottus glenii. Some of the ecological indices were calculated, as well as biodiversity indices (Margalef, Menhinik, Shannon-Wiener), evenness (equitability), and fish stocks. The ecological analysis revealed some interesting aspects of fish communities' structure and also of biodiversity.
\end{abstract}

Key words: fish communities, Siret River, biodiversity

\section{INTRODUCTION}

The importance of the ichthyofauna for the assessment of the water quality is well known, since the fish are among the most sensitive organisms to most of the environmental changes, either of natural or anthropic origin. This is the main reason for scientists to update the scientific data regarding the structure of the fish communities relative to the significant environmental changes in the last decades, mainly induced by the human activities.

\section{MATERIAL AND METHODS}

This research study was carried out in Bacau - Racaciuni section of Siret River, on the main course of the river and on some of its tributaries, during the period 2012-2016. 
The biological material was sampled by electrofishing from 16 sampling sites, and then it was determined and immediately released. An ecological analysis has been done, and some of the biodiversity indices have been calculated, as well as evenness (equitability), and fish stocks.

\section{RESULTS AND DISCUSIONS}

The taxonomic analysis highlights the presence of 27 fish species, two of them being non-native: Psedorasbora parva, and Perccottus glenii.

The frequency of the fish species in sampling sites is represented in the figure 1. The biodiversity indices are revealed in Table 1.

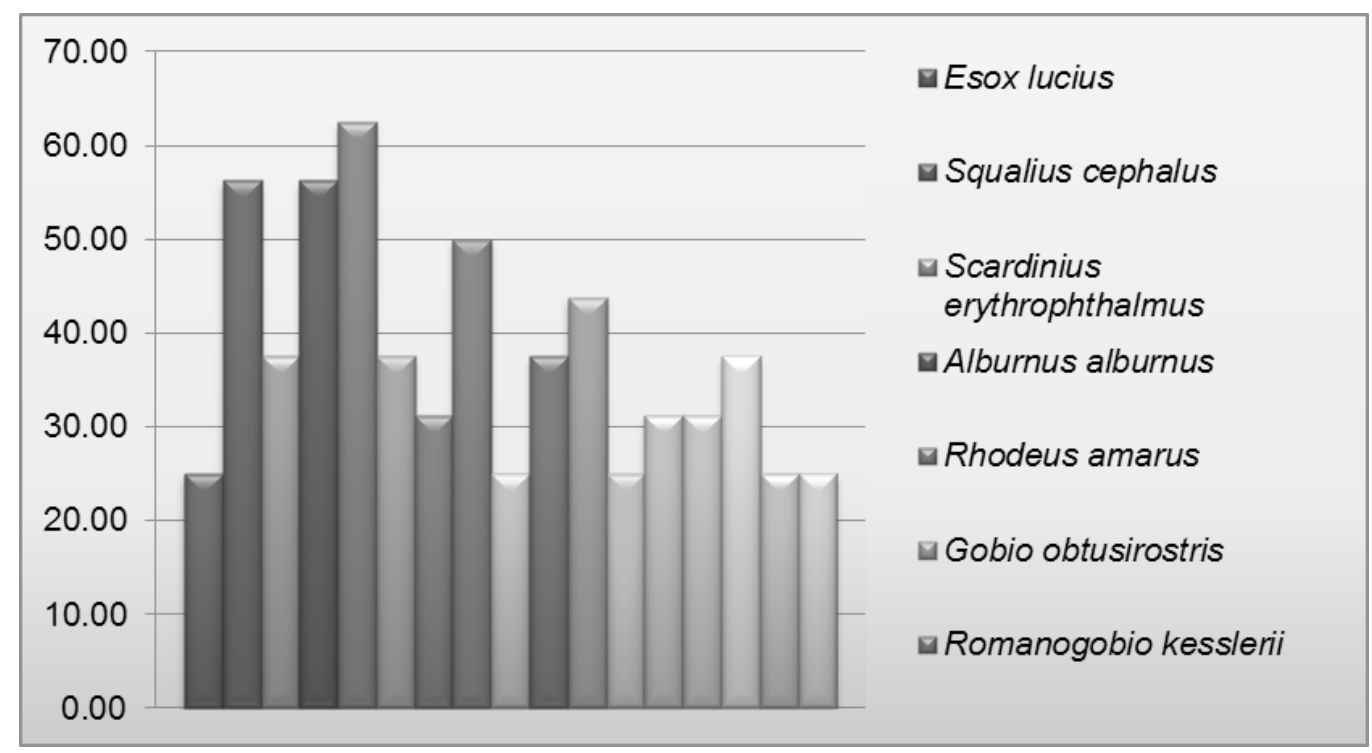

Figure 1. The frequency of the fish species in sampling sites in the section Bacau - Racaciuni of Siret River

Table 1. Biodiversity indices for the fis communities in the section Bacau Racaciuni of Siret River

\begin{tabular}{|c|c|c|c|c|c|c|}
\hline \multirow[b]{2}{*}{$\begin{array}{c}\text { No. of sampling } \\
\text { site }\end{array}$} & \multirow[b]{2}{*}{ No. of fish species } & \multicolumn{2}{|c|}{ Species richness } & \multicolumn{2}{|c|}{ Heterogeneity } & \multirow[b]{2}{*}{ Evenness } \\
\hline & & $\begin{array}{c}\text { D1 } \\
\text { (Margalef) }\end{array}$ & $\begin{array}{c}\text { D2 } \\
\text { (Menhinick) }\end{array}$ & Simpson & $\begin{array}{c}\text { Shannon- } \\
\text { Wiener }(\mathrm{H})\end{array}$ & \\
\hline 1 & 8 & 4,694 & 1,437 & 0,783 & 1,776 & 0,854 \\
\hline 2 & 10 & 4,026 & 0,762 & 0,392 & 0,952 & 0,413 \\
\hline 3 & 11 & 4,074 & 0,652 & 0,773 & 1,703 & 0,710 \\
\hline
\end{tabular}




\begin{tabular}{|c|c|c|c|c|c|c|}
\hline 4 & 13 & 4,488 & 0,598 & 0,767 & 1,725 & 0,673 \\
\hline 5 & 2 & 3,322 & 1,414 & 0,500 & 0,693 & 1,000 \\
\hline 6 & 8 & 2,694 & 0,402 & 0,193 & 0,502 & 0,241 \\
\hline 7 & 13 & 4,130 & 0,458 & 0,582 & 1,147 & 0,447 \\
\hline 8 & 14 & 3,810 & 0,275 & 0,249 & 0,649 & 0,246 \\
\hline 9 & 14 & 4,789 & 0,615 & 0,694 & 1,532 & 0,581 \\
\hline 10 & 3 & 0,952 & 0,267 & 0,291 & 0,561 & 0,511 \\
\hline 11 & 4 & 1,358 & 0,314 & 0,365 & 0,720 & 0,519 \\
\hline 12 & 5 & 1,829 & 0,403 & 0,549 & 0,988 & 0,614 \\
\hline 13 & 5 & 2,406 & 0,737 & 0,309 & 0,692 & 0,430 \\
\hline 14 & 7 & 2,928 & 0,661 & 0,561 & 1,168 & 0,600 \\
\hline 15 & 10 & 4,271 & 0,884 & 0,687 & 1,474 & 0,640 \\
\hline 16 & 7 & 2,994 & 0,697 & 0,546 & 1,093 & 0,562 \\
\hline
\end{tabular}

\section{CONCLUSIONS}

According to the biodiversity indices it can be noticed that the highest heterogeneity was recorded in the sampling sites 1,3,4 in Siret River while the highest equitability was recorded in one of the tributaries, Valea Mare (5).

\section{REFERENCES}

1. Bănărescu P., 1964. Fauna R.P.R., Pisces-Osteichthyes, XIII, Ed. Acad., București.

2. Ureche D., 2008. Studii ecologice asupra ihtiofaunei în bazinul mijlociu și inferior al râului Siret, Ed. Pim, lași. 